\title{
ASERA: an uncontroversial evolution
}

\author{
Stephen M. Ritchie
}

Received: 13 October 2008/Accepted: 13 October 2008/Published online: 22 November 2008

(C) Springer Science+Business Media B.V. 2008

The Australasian Science Education Research Association Ltd. (ASERA) is the oldest educational research association in Australasia. Starting as an informal meeting of science educators at Monash University in May 1970, it has evolved progressively without major controversy into a formally constituted limited company that promotes science education at all levels and contexts.

The history of ASERA is told in two ways in this special issue. A collection of brief historical accounts by researchers at different stages of their careers and representing different eras in ASERA's evolution leads the issue. This is followed by biographies of four distinguished contributors to ASERA; namely, Peter Fensham, Roger Osborne, Léonie Rennie, and Campbell McRobbie. While I could have commissioned several additional biographies of distinguished contributors, these four represent different research groups that had a major impact on ASERA's evolution. Briefly, Peter Fensham was the first professor of science education in Australasia and is recognized as the founder of ASERA. Roger Osborne's participation in ASERA from the late 1970s led to a closer relationship and exchange of ideas between Australian and New Zealand researchers that accelerated the conceptual change movement internationally. Léonie Rennie's research on gender and learning science in contexts other than classrooms legitimated and promoted alternative research agendas (i.e., different from conceptual change), making participation in ASERA even more welcoming for and appealing to a wider section of the research community. Her sustained participation at ASERA conferences also brought researchers from the West and East Coasts of Australia closer together. Campbell McRobbie presided over the most far-reaching and dramatic changes in the organization and management of ASERA. In particular, his entrepreneurial talents were realized during the transformation of ASERA to a limited company and the conversion of Research in Science Education from conference proceedings to an internationally ranked journal published by Springer.

Except in the case of Roger Osborne, once I had decided who the distinguished contributors would be (after consulting with Ken Tobin and Michael Roth, the editors of Cultural Studies of Science Education), I invited each contributor to nominate or approve a

S. M. Ritchie $(\bowtie)$

Queensland University of Technology, Brisbane, Australia

e-mail: s.ritchie@qut.edu.au 
suggested author of the biography. Where necessary, the completed draft was distributed to the author's colleagues for comment and even returned in one or two cases to the distinguished contributor for checking. In this way, the distinguished contributor articles are authorized short biographies. In all cases, a close colleague or former student of the distinguished contributor was selected as author. Dick Gunstone was delighted to be invited to write about Peter Fensham's contribution to ASERA. Dick acknowledges the impact of Peter's mentoring within Monash University where they both worked and he elicited numerous testimonials from international scholars on Peter's legacy to science education research. After discussing the desire to publish an account of Roger Osborne's contribution to ASERA with Alister Jones at Waikato University, John Gilbert was invited to write about Roger's work and impact on ASERA. John and Roger were good friends and colleagues, finetuning new research procedures together to help identify children's understandings of scientific phenomena. Grady Venville worked with Léonie Rennie at Curtin University for several years on major research projects, so that was an obvious choice. Again, Grady consulted with colleagues to illuminate Léonie's impressive contribution. Finally, Greg Thomas was Cam McRobbie's doctoral student at Queensland University of Technology. As he was completing his thesis, Greg also became Cam's editorial assistant for RISE. Because Greg has worked in Hong Kong and Canada since graduating, Keith Skamp was invited to co-author the piece to search out and add the latest information from down under. ${ }^{1}$

The contributors tell their stories in different styles. Perhaps this reflects their personalities and academic backgrounds. Some accounts are factual, others are theoretical, more are narratives, and some are mixed or hybridized genres. In the main, they are positive and affirming-reinforcing an image of a progressive, inclusive, friendly, generous, and informal association. There are no revelations of fractures within the association, and no accounts of major controversy, other than reference to a few grumbles here and there when changes were proposed. So, has the ASERA experience been positive and uplifting for all? Are there unspoken controversies? Can the uncontroversial be made controversial?

It would be ridiculous to suggest that all researchers who attend ASERA feel the same as the insiders whose accounts are reported here. If ever there is mild controversy, the most likely topic for grumbling delegates is the arrangements for the conference dinner. Oversimplifying the dynamics of a conference dinner to illustrate this frivolous issue, two main camps can be identified: the dancers and the talkers. The dancers enjoy loud music and ungainly rhythmic activity, while the talkers enjoy an aged bottle of red to lubricate congenial conversation. The dinner always follows the Annual General Meeting so the topic is never addressed formally. However, the incoming convenors usually resolve the perceived conflict between camps in the following year by privileging the preferences of the grumblers from the previous dinner. So the happy dancers from one year will need to endure, in the following year, more talk and possibly even the dreaded (or, for the talkers, much anticipated) after-dinner speech. More controversially, there is a third camp-those who do not attend. The growing expense may dissuade doctoral students, newcomers may not feel comfortable to socialize with more experienced colleagues, connoisseurs prefer to dine at first class restaurants, and some members from each camp may try to second guess the convenors and opt out of the dinner to avoid their least preferred dinner program.

The enduring issue of power has the greatest potential for creating discontent within ASERA, as in any association. The founding members deliberately avoided hierarchical structures. As we see in the first article, there was no apparent move to "hold onto power"

${ }^{1}$ Colloquial for Australia and sometimes New Zealand, both situated in the Southern Hemisphere. 
as the second and third conferences rolled out, even if it was ever held in some way by Peter Fensham due to his unique position as the only science education professor and his action to invite interested science educators to convene at Monash for the first conference. Peter did not attend the second conference, the venue was changed each year, and volunteers within the association took up administration tasks - an amazing case of distributed leadership.

Australian science education researchers in the 1970s unremarkably were mostly male. Archival records show that Effie Best was an active female member from 1971 after moving to South Australia following the completion of her doctorate in science education from Ohio State University in 1970, making her one of only a few education academics with doctoral qualifications in Australia. By the time I had become a regular member, young female researchers also were starting their careers. For example, Valda Kirkwood and Wilhelmina Van Rooy both attended my second ASERA in 1987. As noted by Vaille Dawson in the first article, it was not until the late 1990s that the proportion of men and women evened out and, unsurprisingly, the formal contribution to ASERA by women through convening responsibilities increased substantially. Despite these trends it is conceivable that some women (and men) who attended ASERA in the 1980s and early 1990s could have felt like outsiders. It is plausible that use of the comical expression The Monash Mafia to refer to the Monash University researchers (that included: Peter Fensham, Dick Tisher, Paul Gardner, Dick White, Dick Gunstone, and Jeff Northfield) might have created the unfortunate stereotype of ASERA being controlled by an intimidating and powerful cadre whose approval was essential for career success. The combination of this potentially dark image and the dominance of conceptual change and cognitive orientations to research might have been a disincentive for some researchers to present papers, especially those that featured approaches with social or cultural orientations. Yet, I remember that Jeff Northfield encouraged my early career research on engaging Aboriginal students in science activities (e.g., Ritchie 1987; Ritchie and Butler 1990), clearly outside the conceptual change group. Possibly in response to fewer scholars attending my early ASERA sessions than mainstream topics, I initiated a parallel program of interpretive research that focussed on teaching science-suggesting I responded to a subtle and unstated message not to venture too far away from sanctioned topics in science education research at ASERA.

Geography also may have played a role in the evolution of ASERA. Domestic airfares during the 1980s were relatively expensive. So much so, I travelled from Brisbane to Sydney overnight by bus to attend one of my early ASERA conferences (i.e., roughly equivalent to the distance between San Diego and San Francisco). This was a time when the cost of an airfare between Sydney and Perth was not much different from an international airfare. This could have worked against diversification of research agendas in ASERA, especially given the growing interest in conceptual change and the strengthening bonds between many East Coast researchers and the Waikato group. West Coast researchers like Ken Tobin and Barry Fraser, whose interests did not align with this movement, found a more receptive audience at the annual meetings of the National Association of Research for Science Teaching (NARST) and the American Education Research Association (AERA) — also attending two conferences with one international airfare. Their regular participation in NARST and AERA, especially in the years when ASERA was hosted on the East Coast, established a different trend for many of the Curtin researchers and their graduate students. These researchers flew over the East Coast across the Pacific to the USA, where their research agendas received recognition and praise. As their profiles within NARST grew, it was interesting for me (as a graduate of Curtin, having been supervised by both Ken and Barry) to observe that, sometimes Monash 
researchers attended the AERA meetings, but not NARST, even when they were convened in the same city. Until recently, I assumed some tension between the West and the East, possibly due to geographic and academic distance.

My once perceived tension between the West and East has dissipated. David Treagust from Curtin has been the Director of ASERA since 2003 and Léonie Rennie continues to participate actively in both ASERA and NARST conferences. Ken Tobin has flown back to Australia for the last two ASERA conferences where he has actively engaged in conversations with early career researchers about socio-cultural issues that impact on learning science. Interestingly, these changes coincide with a reduction in price for domestic air travel and an upsurge in electronic communication. It will be interesting to monitor the impact of the current global financial downturn on airfare prices and conference participation. We now have greater diversity of topics and methodologies listed in the ASERA program each year, and researchers from the East and West share ideas more freely. Further diversification might be achieved by paying greater attention to more inclusive practices for our Northern colleagues from Asian countries. Will ASERA's evolution continue to be uncontroversial?

Acknowledgments In my attempt to make the uncontroversial controversial in this editorial, I consulted with David Treagust, Peter Fensham, Cam McRobbie, Donna King, Vaille Dawson, Kenneth Tobin and Grady Venville. While I am grateful for their comments on particular aspects of the editorial, I take responsibility for the content and the controversy it may cause.

\section{References}

Ritchie, S. M. (1987). Improving the learning environment for aboriginal students in science classes. Research in Science Education, 17, 23-30. doi:10.1007/BF02357168.

Ritchie, S. M., \& Butler, J. (1990). Aboriginal studies and the science curriculum: Affective outcomes from a curriculum intervention. Research in Science Education, 20, 249-254. doi:10.1007/BF02620500.

Stephen M. Ritchie teaches and conducts research at Queensland University of Technology. He is the current Editor of Research in Science Education, the official journal of the Australasian Science Education Research Association Ltd. Steve also maintains ASERA's official webpage at www.asera.org.au. 